\title{
A study to find the correlation between 24 -hour urinary protein and spot urinary albumin to creatinine ratio and to determine the accuracy of spot urinary albumin to creatinine ratio as an indicator to detect proteinuria and its use as a rapid alternative test over 24-hour urinary protein in preeclamptic women
}

\author{
Sowmya Mahesh*, Deepa Borgohain
}

Department of Obstetrics and Gynecology, Assam Medical College and Hospital, Dibrugarh, Assam, India

Received: 03 September 2019

Accepted: 04 October 2019

\section{*Correspondence:}

Dr. Sowmya Mahesh,

E-mail: sowmya_m26@yahoo.com

Copyright: $\odot$ the author(s), publisher and licensee Medip Academy. This is an open-access article distributed under the terms of the Creative Commons Attribution Non-Commercial License, which permits unrestricted non-commercial use, distribution, and reproduction in any medium, provided the original work is properly cited.

\section{ABSTRACT}

Background: Preeclampsia is a multisystem endothelial disease leading to glomeruloendotheliosis with endothelial leak causing significant proteinuria. It is associated with high maternal and fetal risks and fetomaternal morbidity and mortality. Spot urinary albumin to creatinine ratio (ACR) leads to earlier detection of glomerular damage leading to prompt management of preeclamptic patients. To determine the accuracy of Spot Urinary ACR as an indicator to detect proteinuria and its use as a rapid alternative test over 24-hour urinary protein in women with Preeclampsia and to find the correlation between the two.

Methods: Spot urinary ACR was measured in 70 consecutive patients with preeclampsia in Assam Medical College, Dibrugarh. The best cut-off value to differentiate between significant and insignificant proteinuria was calculated. The mean, standard deviation and range of various parameters were computed and various statistical tests were used. The Area under the curve and ROC curve were plotted.

Results: The best cut-off value to differentiate significant and insignificant proteinuria was calculated as $291.9 \mathrm{mg} / \mathrm{g}$ beyond which adverse fetomaternal outcomes and complications were seen. The correlation coefficient between 24hour urinary protein and spot urinary albumin to creatinine ratio was 0.922 highly significant. The area under the curve was found to be 0.98 with a standard error of 0.0155 which implied that the discriminant ability of spot urinary ACR to differentiate significant proteinuria from insignificant proteinuria in patients with preeclampsia was found to be $98 \%$. Similar studies mentioned in the table below showed a good correlation between 24-hour urinary protein estimation and spot urinary ACR.

Conclusions: Compared with 24-hour urinary protein excretion, spot urinary ACR is a simple and accurate indicator of significant proteinuria and helps to detect fetomaternal outcomes in preeclamptic women which may lead to prompt management to reduce fetomaternal complications.

Keywords: Fetomaternal outcomes, Preeclampsia, Proteinuria, ROC curve, Spot urinary albumin to creatinine ratio, 24-hour urine protein

\section{INTRODUCTION}

Pregnancy is a unique state of interaction between two dynamic systems, the mother and the baby. Since each baby has a complement of the father's essence, the woman develops a special talent of immunological, physiological and anatomical tolerance to the new arrangement. There are many disease states that are as a result of father's invasion and pregnancy induced hypertension is one of them. It is an autoimmune 
condition where the mother rejects a foreign body which is the baby.

Preeclampsia is determined by the presence of blood pressure $\geq 140 / 90 \mathrm{mmHg}$ on two occasions at least 4 hours part in a woman with previously normal blood pressure and significant proteinuria defined as the excretion of $\geq 300 \mathrm{mg}$ of protein in a 24 hour urine collection or a timed excretion that is extrapolated to this 24 hour urine value or a protein to creatinine ratio of at least 0.3 (each measured as $\mathrm{mg} / \mathrm{dL}$ ) or a urinary dipstick of $1+$ (recommended only if sole test available) after the 20th Week of gestation (ACOG 2013). ${ }^{1}$

Preeclampsia is a significant contributor of maternal and fetal mortality and it affects $2-8 \%$ of all pregnancies worldwide. Worldwide about 76,000 pregnant women die each year from preeclampsia and related hypertensive disorders. Hypertensive disorders along with sepsis $(10.7 \%)$ are the second most leading cause of maternal mortality after hemorrhage (27.1\%) (WHO 2014). ${ }^{2}$ Fetal deaths due to maternal hypertensive disorders are thought to be in the order of 500,000 per annum. According to WHO, the burden of preeclampsia lies more over developing countries and up to a maximum of $25 \%$ results in maternal death. ${ }^{3}$

According to NICE Guidelines, one of the cornerstones of detection of preeclampsia includes regular measurements of blood pressure and urine analysis for detection and quantification of significant proteinuria which is essential for both diagnosis and assessment of severity of the disease. ${ }^{4}$ The presence of significant proteinuria is associated with higher maternal and fetal risks. A need exists for a simple, rapid, convenient and accurate test to identify significant urinary proteinuria. This may lead to timelier decision-making aimed to decrease the patient's anxiety, reduce both fetal and maternal complications, shorten the length of hospital stay with its associated cost savings and detect women with true pathology for treatment.

Sufficient evidence from previous studies show a strong association between random urinary protein to creatinine ratio (PCR) or albumin to creatinine ratio (ACR) and 24hour urinary protein excretion. However, a consensus has not yet been reached on this ratio's use in detection of fetomaternal outcomes and complications.

The objectives of this study were to determine the accuracy of spot urinary albumin to creatinine ratio as an indicator to detect proteinuria and its use as a rapid alternative test over 24-hour urinary protein in women with preeclampsia. To correlate between 24-hour urinary protein and spot urinary albumin to creatinine ratio.

\section{METHODS}

This was prospective study, conducted in the Assam Medical College and Hospital, Dibrugarh, India. Hospital based study, conducted one year (June 2016 to June 2017). A total 70 sample size. Approval was obtained from the Institutional Ethics Committee.

\section{Inclusion criteria}

- Primigravida with singleton pregnancy with cephalic presentation with intact membranes

- Patients having blood pressure recording of 140/90 $\mathrm{mm} \mathrm{Hg}$ or more on two occasions 4 hours apart or a single diastolic reading of more than or equal to 110 $\mathrm{mm}$ hg after 20th week of pregnancy and the presence of proteinuria $\geq 1+$ as detected by dipstick urine analysis

- All booked and unbooked cases willing for a hospital delivery at Assam Medical College and Hospital Dibrugarh.

\section{Exclusion criteria}

- Women with previous renal disease, chronic hypertension, urinary tract infection, gestational diabetes, connective tissue disorders, epilepsy and pathological vaginal discharge

- Women who developed eclampsia

- Women who required delivery before completion of 24-hour urine sample for any reason whatsoever

- Cases who would have incomplete 24-hour urine collection and proteinuria $<300 \mathrm{mg}$ would be excluded

- Patients not giving written informed consent

- Patients lost to follow up.

A total of 70 consecutive participants depending upon inclusion and exclusion criteria were selected counselled and explained the nature of study. Upon willingness to participate in the study, they were provided with a written and informed consent. A special proforma was made for the study and was filled for every patient who had given full and valid consent to participate in the study. Elaborate history was taken and general physical and obstetric examination were done for every patient in the study. For all cases routine investigations and special investigations like dipstick test for urine albumin in random urine sample, 24-hour urinary protein, spot urinary albumin to creatinine ratio, liver function tests, renal function tests, coagulation profile etc. were done.

\section{Evaluation of proteinuria}

\section{Screening of proteinuria by dipstick method}

For all patients, screening of proteinuria was performed by urinary dipstick method. At the time of admission, random urine samples were tested for protein by a semiquantitative commercially available dipstick by the name of Siemens Uristiks for Glucose and Protein Urinalysis.

Measurement of 24-hour urinary protein 
- Collection and measurement of 24-hour urine collection sample

After admission, the first voided morning urine specimen was discarded. Instructions were given to patients for proper collection of a 24-hour urine specimen. Patients were asked to rest at least for 1 hour in left lateral decubitus to avoid ureteral compression. Twenty-fourhour urine collection was started from 8 am in the morning following admission and was taken till next morning 8 am.

After the collection was complete, the sample was sent to Department of Pathology at AMCH, Dibrugarh. The sample was measured by decanting in a 1 Litre measuring cylinder and hence, the total volume was noted.

- Estimation of 24-hour urinary protein

Esbach's Albuminometer Method was the method used to estimate 24-hour urinary protein.

This method is based on the principle of cold precipitation by strong acids.

- Measurement of spot urinary albumin to creatinine ratio $(\mathrm{ACR})$

\section{Collection of samples}

5-10 mL mid-stream voided urine sample was collected for calculating spot urinary albumin to creatinine ratio immediately after the 24-hour urine collection. This sample was sent to a NABL laboratory nearby $\mathrm{AMCH}$, Dibrugarh. This was made free of cost to the patient.

\section{a. Measurement of urinary albumin}

Spot urinary albumin was calculated by MALB method by an automated analyser (Dimension Xpand plus) by Siemens based on a technique called PETINA (particleenhanced turbidimetric inhibition immuno assay) which allows direct quantification of proteins.

\section{b. Measurement of urinary creatinine}

Spot urinary creatinine was calculated by the CREA Method by an Automated Analyser (Dimension Xpand Plus) by Siemens and was determined by Jaffe's Reaction. In this method, in the presence of a strong base like sodium hydroxide $(\mathrm{NaOH})$, picrate reacts with creatinine to form a red chromophore.

\section{Calculations}

The spot urinary albumin to creatinine ratio was obtained by dividing the urinary albumin concentration by the urinary creatinine concentration.

$$
\begin{aligned}
& \text { Urinary } \\
& \begin{array}{l}
\text { Albumin to } \\
\text { Creatinine } \\
\text { Ratio }(\mathrm{mg} / \mathrm{g})
\end{array} \quad=\frac{\begin{array}{l}
\text { Concentration of Urinary } \\
\text { Albumin }(\mathrm{mg} / \mathrm{L})
\end{array}}{\begin{array}{l}
\text { Concentration of Urinary } \\
\text { Creatinine }(\mathrm{mg} / \mathrm{dl})
\end{array}} \times 100
\end{aligned}
$$

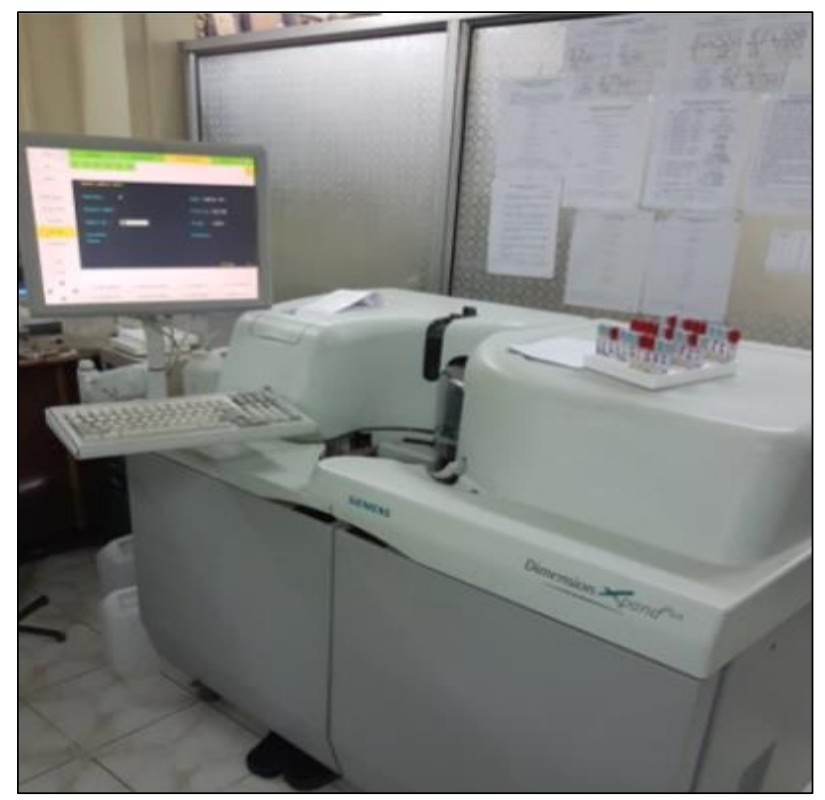

Figure 1: The Siemens's Dimension Xpand Plus machine used for calculating spot albumin to creatinine ratio.

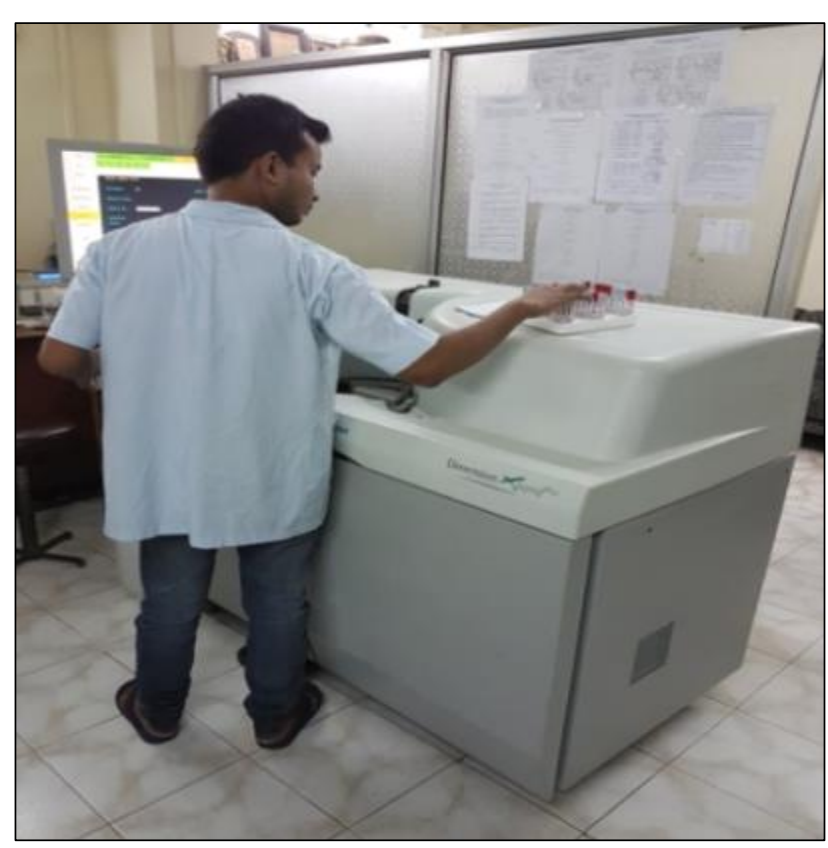

Figure 2: The standardised technology being used for calculating spot albumin to creatinine ratio by a laboratory worker.

Labour was recorded in the modified WHO partograph. New-borns were attended by paediatrician and were 
examined thoroughly and any complication was duly noted and managed accordingly. Blood pressure record was maintained after delivery till discharge. On discharge, patients were advised to follow up after 6 weeks.

\section{Statistical analysis}

The data collected was analyzed by appropriate statistical methods. The mean, standard deviation and range of various parameters were computed. The statistical tests used for analysis were Pearson's Correlation Co-efficient expressed as 'r', Kruskal-Wallis equality-of-population rank test using Dunn's pairwise comparison expressed as $x^{2}$ and Wilcoxon Rank-Sum (Mann-Whitney) Test. Using analysis of variance, a $\mathrm{p}$ value $<0.05$ was considered to be statistically significant.

\section{RESULTS}

All the patients were studied with respect to sociodemographic characteristics and obstetrical parameters and the data has been shown in the following tables. The study aimed at determining the correlation between 24 hour urinary protein and spot urinary albumin to creatinine ratio and their association with fetomaternal outcomes.

The mean age, BMI, gestational age, blood pressures, 24hour urine protein and spot albumin to creatinine ratio have been calculated for the sample size in the study.

Table 1: Socio-demographic, obstetrical and laboratory parameters.

\begin{tabular}{|ll|}
\hline Characteristics & Mean \pm SD \\
\hline Mean age (years) & $23.73 \pm 3.65$ \\
\hline Mean BMI $\left(\mathrm{kg} / \mathrm{m}^{2}\right.$ ) & $20.19 \pm 1.49$ \\
\hline Mean gestational age (weeks) & $36.36 \pm 1.62$ \\
\hline Number of antenatal visits & $3.46 \pm 1.22$ \\
\hline $\begin{array}{l}\text { Mean systolic blood pressure } \\
\text { (mmHg) }\end{array}$ & $155.26 \pm 10.08$ \\
\hline $\begin{array}{l}\text { Mean systolic blood pressure } \\
\text { (mmHg) }\end{array}$ & $102.11 \pm 7.04$ \\
\hline $\begin{array}{l}\text { Mean 24-hour urinary protein } \\
\text { (mg/day) }\end{array}$ & $1284.29 \pm 844.40$ \\
\hline $\begin{array}{l}\text { Mean spot urinary albumin to } \\
\text { creatinine ratio (ACR) (mg/gm) }\end{array}$ & $1812.44 \pm 1162.58$ \\
\hline
\end{tabular}

Table 2: Tests of validity of spot urinary albumin to creatinine ratio (at $300 \mathrm{mg} / \mathrm{g}$ ) in prediction of significant proteinuria $(=300 \mathrm{mg} / \mathrm{day})$.

\begin{tabular}{|llll|}
\hline $\begin{array}{l}\text { Spot urinary albumin to creatinine ratio } \\
(\mathbf{m g} / \mathrm{gm})\end{array}$ & $\mathbf{2 4}$ hour urinary protein (mg/day) & Total \\
\hline$\geq 300$ & $\mathbf{3 0 0}$ & $\mathbf{3 0 0}$ & 59 \\
\hline$<300$ & 57 & 2 & 11 \\
\hline Total & 3 & 10 & 70 \\
\hline Sensitivity & 60 & & \\
\hline Specificity & $95 \%$ & & \\
\hline PPV & $80 \%$ & & \\
\hline NPV & $96.6 \%$ & & \\
\hline
\end{tabular}

Table 3: Comparison of urinary dipstick with 24-hour urinary protein estimation.

\begin{tabular}{|c|c|c|c|}
\hline \multirow{2}{*}{ Urinary dipstick grading } & \multicolumn{2}{|c|}{ 24-hour urinary protein (mg/day) } & \multirow{2}{*}{ Total } \\
\hline & $\geq \mathbf{3 0 0}$ & $<300$ & \\
\hline$=3+($ positive $)$ & 51 & 2 & 53 \\
\hline$=2+($ negative $)$ & 9 & 8 & 17 \\
\hline Total & 60 & 10 & 70 \\
\hline Sensitivity & \multicolumn{3}{|l|}{$85 \%$} \\
\hline Specificity & \multicolumn{3}{|l|}{$80 \%$} \\
\hline PPV & \multicolumn{3}{|l|}{$96.2 \%$} \\
\hline NPV & \multicolumn{3}{|l|}{$47.0 \%$} \\
\hline
\end{tabular}

Tables 2, 3 and 4 compared the two tests-urinary dipstick and spot urinary albumin to creatinine ratio with 24-hour urinary protein. The sensitivity of the two tests showed that spot urinary albumin to creatinine of at $300 \mathrm{mg} / \mathrm{gm}$ had a better sensitivity of $95 \%$ as compared to the urinary dipstick which had an $85 \%$ sensitivity. The specificity of both tests was $80 \%$.

The positive predictive value of the two tests showed that spot urinary albumin to creatinine at $300 \mathrm{mg} / \mathrm{gm}$ had a 
PPV of $96.6 \%$ as compared to the urinary dipstick which had a PPV of $96.2 \%$. The negative predictive value of the two tests showed that spot urinary albumin to creatinine at $300 \mathrm{mg} / \mathrm{gm}$ had an NPV of $72.7 \%$ as compared to the urinary dipstick which had a NPV of $47 \%$.

In the present study, a cut-off value of spot urinary albumin to creatinine ratio that predicted significant proteinuria in a 24-hour urine collection was calculated at different levels of spot urinary albumin to creatinine ratio (Table 5).
Table 4: Comparison of tests of validity between spot urinary albumin to creatinine ratio and urinary dipstick.

\begin{tabular}{|ll|l|}
\hline $\begin{array}{l}\text { Tests of } \\
\text { validity }\end{array}$ & $\begin{array}{l}\text { Spot urinary albumin } \\
\text { to creatinine ratio } \\
\text { (at } 300 \mathrm{mg} / \mathrm{g} \text { ) }\end{array}$ & $\begin{array}{l}\text { Urinary } \\
\text { dipstick } \\
\text { (at }+3 \text { level) }\end{array}$ \\
\hline Sensitivity & $95 \%$ & $85 \%$ \\
\hline Specificity & $80 \%$ & $80 \%$ \\
\hline PPV & $96.6 \%$ & $96.2 \%$ \\
\hline NPV & $72.7 \%$ & $47.0 \%$ \\
\hline
\end{tabular}

Table 5: Determination of cut-off value and comparison of different cut-off values of spot urinary albumin to creatinine ratio in prediction of significant proteinuria.

\begin{tabular}{|lllll|}
\hline Urinary albumin to creatinine ratio cut-ofi value (mg/gm) & Sensitivity $(\%)$ & Specificity $(\%)$ & PPV (\%) & NPV (\%) \\
\hline 200 & 98 & 29 & 93 & 67 \\
\hline 250 & 100 & 60 & 94 & 100 \\
\hline 300 & 95 & 80 & 97 & 73 \\
\hline 350 & 95 & 80 & 97 & 73 \\
\hline 400 & 95 & 80 & 97 & 73 \\
\hline 450 & 95 & 80 & 97 & 73 \\
\hline
\end{tabular}

Table 6: Correlation between spot urinary albumin to creatinine ratio and 24-hour urinary protein.

\begin{tabular}{|llllllllll|}
\hline $\begin{array}{l}\text { Spot urinary alloumin to } \\
\text { creatinine ratio }(\mathbf{m g} / \mathrm{gm})\end{array}$ & $\mathbf{n}$ & $\mathbf{\%}$ & Mean & SD & Range & & $r^{2}$ & p value \\
\hline$<300$ & 11 & 15.71 & 381.82 & 297.72 & $200.00-1000.00$ & 0.658 & 0.434 & $\mathrm{p}$ value $=0.027$ \\
\hline $300-2999$ & 49 & 70.00 & 1172.45 & 420.70 & $200.00-2250.00$ & 0.906 & 0.822 & $\mathrm{p}$ value $<0.05$ \\
\hline$\geq 3000$ & 10 & 14.29 & 2825.01 & 850.2 & $2250.00-5000.00$ & 0.845 & 0.715 & $\mathrm{p}$ value $=0.002$ \\
\hline All values & 70 & 100.00 & 1284.29 & 844.40 & $200.00-5000.00$ & 0.922 & 0.851 & $\mathrm{p}$ value $<0.05$ \\
\hline
\end{tabular}

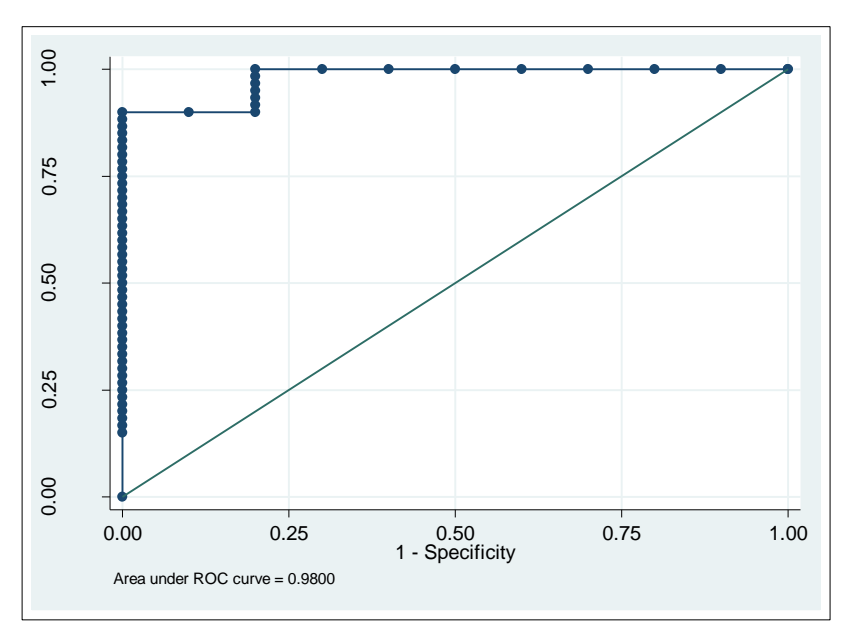

Figure 3: Receiver operator characteristic curve analysis.

Description (Figure 3), ROC curve gave the most discriminant value for spot urinary albumin to creatinine ratio of $291.9 \mathrm{mg} / \mathrm{gm}$ for detecting significant proteinuria ( $\geq 300 \mathrm{mg} /$ day) which gave the best sensitivity, specificity, positive predictive value and negative predictive values. The spot urinary albumin to creatinine ratio at $291.9 \mathrm{mg} / \mathrm{gm}$ yielded a sensitivity of $98.33 \%$ and a specificity of $80 \%$. The area under the curve was 0.98 with a standard error of 0.0155 and a confidence interval between 0.94 and 1.00. The discriminant ability of spot urinary albumin to creatinine ratio to differentiate significant proteinuria from insignificant proteinuria in patients with preeclampsia was found to be $98 \%$.

Table 6 shows the correlation between 24-hour urinary protein and different ranges of proteinuria detected by spot urinary albumin to creatinine ratio. Overall a good correlation was achieved between all values of spot urinary albumin to creatinine ratio and 24-hour urinary protein with a correlation coefficient of 0.922 and $p$ value $<0.05$ which was statistically significant. There was a good correlation between spot urinary albumin to creatinine ratio $<300.0 \mathrm{mg} / \mathrm{gm}$ and 24-hour urinary protein with a correlation coefficient of 0.658 . The $p$ value was found to be 0.027 which was statistically significant. 
Also, there was good correlation between spot urinary albumin to creatinine ratio between $300.0 \mathrm{mg} / \mathrm{gm}$ and $2999 \mathrm{mg} / \mathrm{gm}$ and 24-hour urinary protein and a correlation coefficient of 0.906 was achieved. The $p$ value was calculated as $<0.05$ which was statistically significant. A good correlation between spot urinary albumin to creatinine ratio $\geq 3000.0 \mathrm{mg} / \mathrm{gm}$ and 24 -hour urinary protein and was achieved with a correlation coefficient of 0.845 . The $p$ value was found to be 0.002 which was statistically significant.

\section{Scatter diagrams showing correlation between spot urinary albumin to creatinine ratio to 24-hour urinary protein}

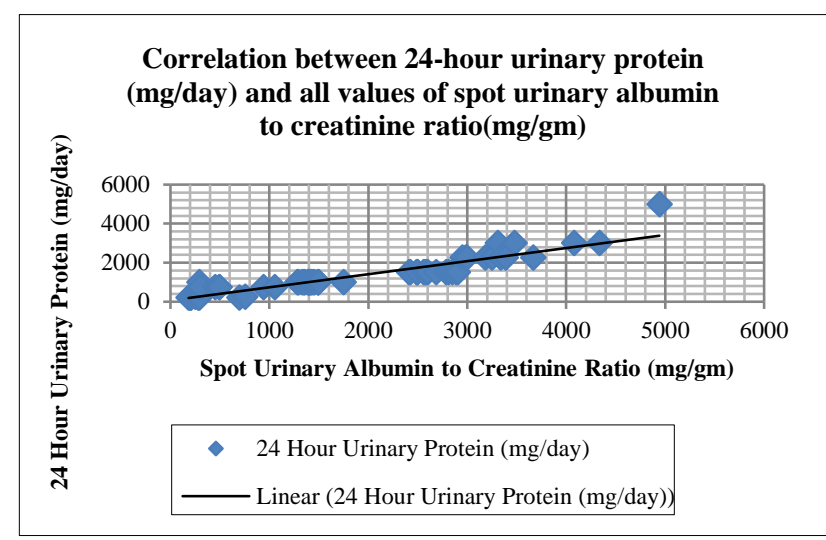

Figure 4: For all values of spot urinary albumin to creatinine ratio.

Description (Figure 4): The above scatter diagram (Figure 4) shows correlation between all values of spot urinary albumin to creatinine ratio and 24-hour urinary protein. The diagram shows a strong positive correlation which means that high spot urinary albumin to creatinine ratio values ( $\mathrm{x}$ variable) go with high 24-hour urinary protein values (y variable). The correlation coefficient was 0.922 . The $\mathrm{p}$ value was $<0.05$ which was statistically significant.

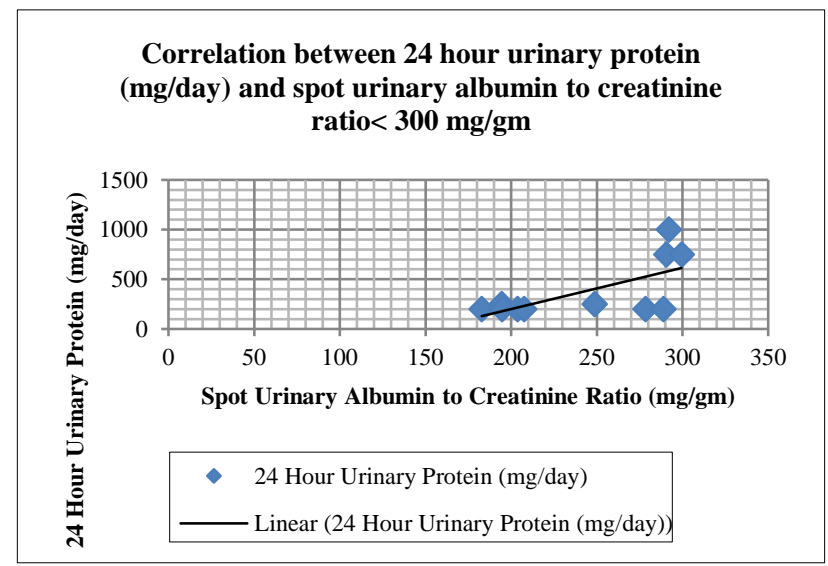

Figure 5: For values of spot urinary albumin to creatinine ratio $<300 \mathrm{mg} / \mathrm{gm}$.
Description (Figure 5): The above scatter diagram (Figure 5) shows correlation between all values of spot urinary albumin to creatinine ratio $<300 \mathrm{mg} / \mathrm{gm}$ with 24 hour urinary protein. The diagram shows a moderate positive correlation, which means there is a tendency for high spot urinary albumin to creatinine ratio ( $\mathrm{x}$ variable) values go with high 24-hour urinary protein values (y variable).

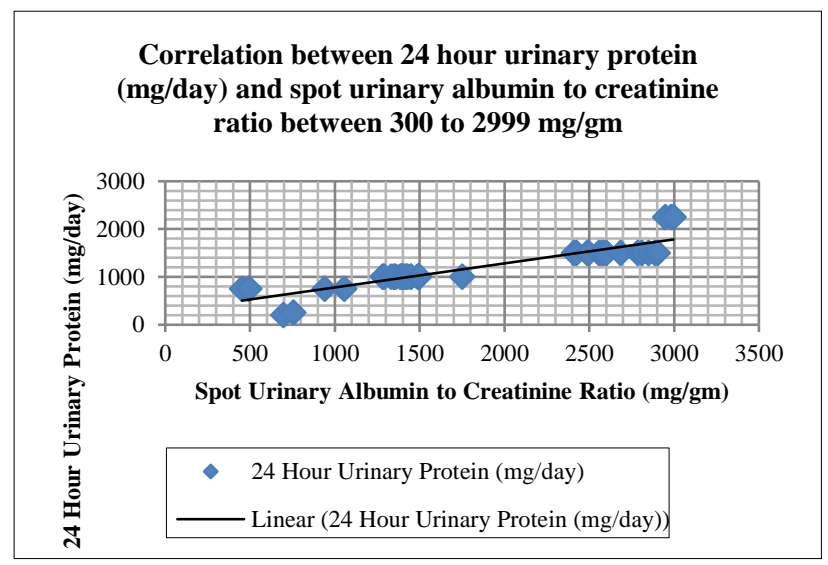

Figure 6: For values of spot urinary albumin to creatinine ratio between 300 to $2999 \mathrm{mg} / \mathrm{gm}$.

The correlation coefficient was 0.658 . The $\mathrm{p}$ value was 0.027 which was found to be statistically significant.

Description (Figure 6): The above scatter diagram (Figure 6) shows correlation between all values of spot urinary albumin to creatinine ratio $300-2999 \mathrm{mg} / \mathrm{mg}$ with 24-hour urinary protein. The diagram shows a strong positive correlation which means that high spot urinary albumin to creatinine ratio values ( $\mathrm{x}$ variable) go with high 24-hour urinary protein values (y variable).

The correlation coefficient was 0.906 . The $\mathrm{p}$ value was $<0.05$ which was statistically significant.

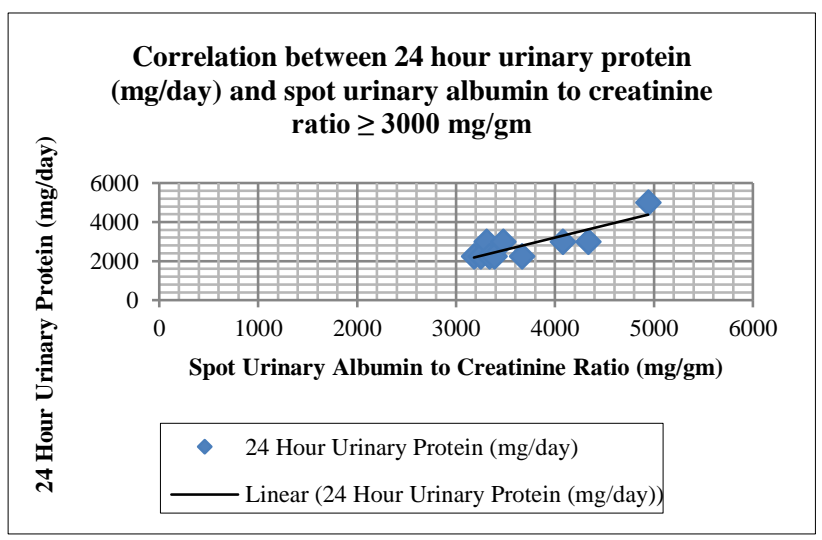

Figure 7: For values of spot urinary albumin to creatinine ratio $\geq 3000 \mathrm{mg} / \mathrm{gm}$.

Description (Figure 7): The above scatter diagram (Figure 7) shows correlation between all values of spot 
urinary albumin to creatinine ratio $\geq 3000 \mathrm{mg} / \mathrm{gm}$ with 24 hour urinary protein. The diagram shows a strong positive correlation which means that high spot urinary albumin to creatinine ratio values ( $\mathrm{x}$ variable) go with high 24-hour urinary protein values (y variable). The correlation coefficient was 0.845 . The $p$ value was 0.002 which was found to be statistically significant.

\section{DISCUSSION}

In the present study, the correlation coefficient between 24-hour urinary protein and spot urinary albumin to creatinine ratio was 0.922 with $\mathrm{p}$ value $<0.05$ which was highly significant. From the ROC curve analysis, the area under the curve was found to be 0.98 with a standard error of 0.0155 with a confidence interval between 0.94 and 1.00 which implied that the discriminant ability of spot urinary albumin to creatinine ratio to differentiate significant proteinuria from insignificant proteinuria in patients with preeclampsia was found to be $98 \%$. Similar studies mentioned in the table below showed a good correlation between 24-hour urinary protein estimation and spot urinary albumin to creatinine ratio. The ROC curve analysis for AUC estimation in the below mentioned studies was also comparable to the present study.

Rodriguez et al, and Huang et al, conducted 2 similar studies and found the correlation coefficient between 24hour urinary protein and spot urinary albumin to creatinine ratio to be 0.80 and 0.938 respectively. ${ }^{11,12}$ The AUC in their studies was 0.91 and 0.918 respectively. Both studies showed a $p$ value of $<0$. 001. The result of the present study was similar to the results reported by Risberg et al, Yamasmit et al, and Shreya et al. 5,6,10
Table 7: The ROC curve analysis for AUC estimation compared to ROC curve analysis in similar studies.

\begin{tabular}{|c|c|c|c|}
\hline Study & $\mathbf{R}$ & p value & AUC \\
\hline Risberg et $\mathrm{al}^{5}$ & 0.95 & $<0.001$ & 0.985 \\
\hline Yamasmit et $\mathrm{al}^{6}$ & 0.95 & - & 0.97 \\
\hline Wheeler et $\mathrm{al}^{7}$ & 0.88 & - & 0.86 \\
\hline Shahbazian et al $^{8}$ & 0.84 & $<0.001$ & - \\
\hline Demirci et $\mathrm{al}^{9}$ & 0.758 & - & 0.89 \\
\hline Shreya at el ${ }^{10}$ & 0.84 & $<0.001$ & 0.92 \\
\hline Present study & 0.922 & $<0.05$ & 0.98 \\
\hline
\end{tabular}

In the present study, the most discriminant value for spot urinary albumin to creatinine ratio for detecting significant proteinuria ( $\geq 300 \mathrm{mg} /$ day in a 24 -hour urine collection) was found to be $291.9 \mathrm{mg} / \mathrm{gm}$ which yielded a sensitivity of $98.33 \%$ and a specificity of $80 \%$. The table below shows similar studies with the best cut-off values of spot urinary albumin to creatinine ratio for detecting significant proteinuria.

Rizk et al, from the ROC curve analysis reported the optimal cut-off value for spot urinary protein to creatinine ratio to detect significant proteinuria was $>190 \mathrm{mg} / \mathrm{gm}$ with a sensitivity of $80.4 \%$ and specificity of $68.8 \% .^{14}$ Demirci et al, reported that the optimal cut-off value for spot urinary protein to creatinine ratio to detect significant proteinuria was $450 \mathrm{mg} / \mathrm{gm}$ with a sensitivity of $74.4 \%$ and specificity of $94.2 \% .^{15}$ The result of the present study was similar to that found in most of the previous studies in terms of the best cut-off value of spot urinary albumin to creatinine ratio to detect significant proteinuria.

Table 8: Comparison of cut-off value of spot urinary albumin to creatinine ratio in prediction of significant proteinuria.

\begin{tabular}{|c|c|c|c|c|}
\hline Study & $\begin{array}{l}\text { 24-hour urinary protein cut- } \\
\text { off (mg/day) }\end{array}$ & $\begin{array}{l}\text { Spot urinary albumin to creatinine } \\
\text { cut-off value (mg/gm) }\end{array}$ & $\begin{array}{l}\text { Sensitivity } \\
(\%)\end{array}$ & $\begin{array}{l}\text { Specificity } \\
(\%)\end{array}$ \\
\hline Risberg et $\mathrm{al}^{5}$ & 300 & 270 & 95 & 100 \\
\hline Yamasmit et al ${ }^{6}$ & 300 & 250 & 96.6 & 92.3 \\
\hline Wheeler et $\mathrm{al}^{7}$ & 300 & 210 & 86.8 & 77.6 \\
\hline Huang et al ${ }^{12}$ & 300 & 228 & 82.4 & 99.4 \\
\hline Kayatas et $\mathrm{al}^{13}$ & 300 & 280 & 60.4 & 77.8 \\
\hline Shreya et al ${ }^{10}$ & 300 & 200 & 91.2 & 87.8 \\
\hline Present study & 300 & 291.9 & 98.33 & 80 \\
\hline
\end{tabular}

\section{CONCLUSION}

Diagnosing proteinuria and its correlation with fetomaternal outcomes and complications in preeclampsia by 24-hour urinary protein estimation is a frustrating task for the obstetrician due to a long delay for results. Alternative testing methods like spot urinary albumin to creatinine ratios or spot urinary protein to creatinine ratios have correlated well with this gold standard method and the risk of adverse maternal and fetal outcomes was found to increase with higher values of spot urinary albumin to creatinine ratio.

Hence, the spot urinary ACR is a reliable, faster and accurate method for detection of proteinuria in preeclampsia and may allow better management of 
women with preeclampsia, thereby decreasing maternal as well as perinatal morbidity and mortality. This test could be used as an alternative to 24-hour urinary protein estimation in detection of significant proteinuria and better prediction of maternal and fetal outcomes in women with preeclampsia. However, further studies on a larger population may be required to consolidate the findings of the study.

\section{Funding: No funding sources}

Conflict of interest: None declared

Ethical approval: The study was approved by the Institutional Ethics Committee

\section{REFERENCES}

1. American College of Obstetricians and Gynecologists. Hypertension in pregnancy. Report of the American College of Obstetricians and Gynecologists' task force on hypertension in pregnancy. Obstet Gynecol. 2013;122(5):1122.

2. Say L, Chou D, Gemmill A, Tunçalp Ö, Moller A, Daniels J, et al. Global causes of maternal death: a WHO systematic analysis. The Lancet Global Health. 2014;2(6):e323-e333.

3. WHO U. UNFPA, Maternal Mortality in 2005: estimates developed by WHO, UNICEF, UNFPA, and the World Bank. World Health Organization, Geneva, Switzerland. 2007. Available at: https://www.who.int/whosis/mme_2005.pdf Accessed on $9^{\text {th }}$ September 2019.

4. National Institute for Health and Care Excellence. Antenatal Care. NICE Clinical Guideline 62. London: NICE; 2008. Available at: https://www.nice.org.uk/guidance/cg62/resources/ant enatal-care-for-uncomplicated-pregnancies-pdf975564597445 Accessed on $9^{\text {th }}$ September 2019.

5. Risberg, Larsson, Olsson, Lyrenäs, Sjöquist. Relationship between urinary albumin and albumin/creatinine ratio during normal pregnancy and pre-eclampsia. Scand $\mathbf{J}$ Clin Lab Invest. 2004;64(1):17-24.

6. Yamasmit W, Chaithongwongwatthana S, Charoenvidhya D, Uerpairojkit B, Tolosa J. Random urinary protein-to-creatinine ratio for prediction of significant proteinuria in women with preeclampsia. The J Maternal-Fetal Neo Med. 2004;16(5):275-9.

7. Wheeler TL, Blackhurst DW, Dellinger EH, Ramsey PS. Usage of spot urine protein to creatinine ratios in the evaluation of preeclampsia. Am J Obstet Gynecol. 2007;196(5):465-e1.

8. Shahbazian N, Hosseini-Asl F. A comparison of spot urine protein-creatinine ratio with 24-hour urine protein excretion in women with preeclampsia. Iranian J Kid Dis. 2008;2(3):127-31.

9. Demirci O, Kumru P, Arınkan A, Ardıç C, Arısoy R, Tozkır E, et al. Spot protein/creatinine ratio in preeclampsia as an alternative for 24-hour urine protein. Balkan Med J. 2015;32(1):51.

10. Shreya G, Pranathi L, Kavitha V. Comparison of spot urine protein-creatinine ratio with 24-hour urine protein excretion in women with preeclampsia. Int $\mathbf{J}$ Integrat Med Sci. 2015;2(1):55-9.

11. Rodriguez-Thompson D, Lieberman ES. Use of a random urinary protein-to-creatinine ratio for the diagnosis of significant proteinuria during pregnancy. Am J Obstet Gynecol. 2001;185(4):80811.

12. Huang Q, Gao Y, Yu Y, Wang W, Wang S, Zhong M. Urinary spot albumin: creatinine ratio for documenting proteinuria in women with preeclampsia. Reviews Obstet Gynecol. 2012;5(1):9.

13. Kayatas S, Erdogdu E, Cakar E, Yilmazer V, Arınkan SA, Dayicioglu VE. Comparison of 24-hour urinary protein and protein-to-creatinine ratio in women with preeclampsia. Eu J Obstet Gynecol Repro Biol. 2013;170(2):368-71.

14. Rizk DE, Agarwal MM, Pathan JY, Obineche EN. Predicting proteinuria in hypertensive pregnancies with urinary protein-creatinine or calcium-creatinine ratio. J Perinatol. 2007;27(5):272.

15. Demirci O, Kumru P, Arınkan A, Ardıç C, Arısoy R, Tozkır E, et al. Spot protein/creatinine ratio in preeclampsia as an alternative for 24-hour urine protein. Balkan Med J. 2015;32(1):51.

Cite this article as: Mahesh S, Borgohain D. A study to find the correlation between 24-hour urinary protein and spot urinary albumin to creatinine ratio and to determine the accuracy of spot urinary albumin to creatinine ratio as an indicator to detect proteinuria and its use as a rapid alternative test over 24-hour urinary protein in preeclamptic women. Int $\mathbf{J}$ Reprod Contracept Obstet Gynecol 2019;8:4358-65. 